Article

\title{
Simple Is Best: Pine Twigs Are Better Than Artificial Lures for Trapping of Pine Weevils in Pitfall Traps
}

\author{
Michal Lalík ${ }^{1,2, *}$, Jaroslav Holuša ${ }^{2}$, Juraj Galko ${ }^{1}$, Karolína Resnerová ${ }^{2}$, Andrej Kunca ${ }^{1}$, \\ Christo Nikolov ${ }^{1}$, Silvia Mudrončeková ${ }^{3}$ and Peter Surový ${ }^{2}$ D \\ 1 National Forest Centre, Forest Research Institute Zvolen, T. G. Masaryka 22, 96001 Zvolen, Slovakia \\ 2 Department of Forest Protection and Entomology, Faculty of Forestry and Wood Sciences, Czech University \\ of Life Sciences Prague, Kamýcka 1176, 16500 Prague, Czech Republic \\ 3 Research Station of State Forests of TANAP, 05960 Tatranská Lomnica, Slovakia \\ * Correspondence: michal.lalik@nlcsk.org; Tel.: +42-19-0374-6426
}

Received: 26 June 2019; Accepted: 22 July 2019; Published: 29 July 2019

check for updates

\begin{abstract}
The large pine weevil Hylobius abietis (Linnaeus 1758) is the main pest of coniferous seedlings in Europe and causes substantial damage in areas that have been clear-cut or otherwise disturbed. We compared the efficacy of different attractants for the capture of H. abietis adults in white pitfall traps. The field experiment was performed from mid-April to the end of August 2018 at six plots in Central Europe located in spruce stands that had been clear-cut. At each plot, we compared five attractants: one pine twig with ethanol, Hylodor, alpha-pinene + ethanol, turpentine oil and ethanol (separated), and turpentine oil + ethanol (not separated). Traps without attractant served as a control. Six traps for each attractant or control were distributed at each plot. Of the total number of H. abietis adults trapped, $43.3 \%, 20.5 \%, 17.9 \%, 9.8 \%, 8.5 \%$ and $0.5 \%$ were captured in traps with pine twigs with ethanol, alpha-pinene, Hylodor, turpentine, oil + ethanol (separated), turpentine oil + ethanol (combined), and no attractant, respectively. The bottom of each trap contained propylene glycol to kill and preserve beetles. The small number of beetles captured in the control traps confirms that the propylene glycol:water mixture did not influence the trapping of $H$. abietis. The use of pitfall traps with a suitable attractant (especially pine twigs and ethanol) should be useful for monitoring of $H$. abietis, because it is simple and cost-effective. The use of such pitfall traps to control H. abietis by mass trapping would require 50 to 100 traps per ha.
\end{abstract}

Keywords: Hylodor; alpha-pinene; turpentine oil; ethanol; propylene-glycol; Norway spruce

\section{Introduction}

The large pine weevil Hylobius abietis (Linnaeus 1758) (Coleoptera: Curculionidae) is the main pest of coniferous seedlings in Europe and is especially damaging in areas where seedlings have been planted following clearcutting or other disturbances [1-3]. In such areas, the presence of fresh stumps maintains high numbers of $H$. abietis. Over the last 100 years, foresters have used various methods to protect seedlings from the damage caused by $H$. abietis feeding [1,3,4].

The basic protection method is to prevent $H$. abietis from feeding on seedlings. Feeding barriers have been commonly used in Germany since 1920 [1]. Plastic collars were developed at the end of the 1970s [5] and have been in use since that time. During the late 1980s and the beginning of the 1990s, researchers developed and tested several other shields, including stockings [6], plastic fibre wrappings ("BEMA") [7], and coated barriers [8]. Feeding can also be prevented by applying various coatings to the seedling stem. The first coating used was latex, which prevented feeding on the bark [9]. Protection can also be provided by a sand coating, which involves an initial application of acrylate glue and a subsequent application of fine sand (grain size $<0.2 \mathrm{~mm}$ ). The treated seedlings can then be planted in 
stands [10]. Another option is to coat seedlings up to a height of $15 \mathrm{~cm}$ with a special flexible wax, which can protect the seedlings for 2 years [11].

All of the methods mentioned in the previous paragraph protect seedlings but do not reduce the numbers of H. abietis in the environment. From the 1950s to 1970s, the development of barriers for the protection of seedlings slowed, because insecticides with dichlorodiphenyltrichloroethane (DDT) were used. Because DDT can harm humans [12] and other non-targets [13], pesticides containing DDT were gradually restricted and finally forbidden. After insecticides with DDT were banned, research concerning the development of other insecticides increased. Pyrethrins and synthetic pyrethroids are sold as commercial pesticides used to control pest insects in agriculture, homes, communities, restaurants, hospitals, schools, and as a topical head lice treatment [14]. Because of physiological effects of synthetic pyrethroids on $H$. abietis [15-18], synthetic pyrethroids are used in the field [19-21].

The mass trapping of $H$. abietis using attracting materials was practised before seedling protection. Mass trapping appears in the literature by 1839 [22]. The materials used to attract $H$. abietis included "trap barks", "trap logs", or fresh branches. In each case, the bark, logs, or branches (which were obtained from host species) were deployed in the field and then removed along with attracted beetles after some period of time. A disadvantage was that the attracted adults remained alive and had to be collected and killed. Trap barks were made more attractive by free placing pine twigs inside two pieces of spruce barks [23].

The labour needed to collect $H$. abietis from trap barks can be reduced by treating the bark with a synthetic pyrethroid or other insecticide such that the beetles are killed. In Europe, however, this method is currently only being used in a few countries [3,24,25]. The main reasons for the decreased use of this seedling protection method is the difficulty in preparing trap barks and the need for their frequent inspection and replacement.

Another method of catching H. abietis adults without the need to collect them is to use pitfall traps. Low numbers of traps are used (20-30 traps per ha), for monitoring [26]. The installation of pitfall traps is simple, and their efficacy is increased by addition of an attractant. Many kinds of attractants have been used, including wooden cylinders and discs [27-30], but the original lure from trap barks, i.e., pine twigs [23], has been forgotten. Only a single modern work uses twigs from Norway spruce in addition to bark [31].

Alpha-pinene combined with ethanol is highly attractive to H. abietis, which is understandable, because alpha-pinene is one of the compounds in the resin of coniferous [32]. Traps containing alpha-pinene with ethanol are more effective than traps that contain only alpha-pinene or only ethanol [33]. These attractants have usually involved the use of two "evaporators" (the containers holding the attractant and releasing its odours) per pitfall trap, i.e., alpha-pinene in one evaporator and $70 \%$ ethanol in a second evaporator [32,34-36]. These chemicals have also been applied to increase the attractiveness of bark and other natural materials [29].

Pitfall traps with attractants can be used both to monitor and control pest populations [27,30]. Such traps, along with chemical protection of seedlings, have been widely used in Poland [37]. Traps IBL-4 containing Hylodor, the aggregation pheromone of $H$. abietis [38], caught significantly more of H. abietis than natural (branches, discs) baits [30].

The pitfall traps used to trap H. abietis are usually simple containers or tubes [31-35,39]. The containers or tubes are buried in the soil, but their tops, which extend above the soil surface, have holes at the soil surface that enable beetles to enter. A recent trend is to create more complex constructions, such as a funnel with holes and a bottle [36], or other types of traps used in Poland [38].

The goal of this work was to evaluate the ability of simple pitfall traps (small buckets) to capture H. abietis adults. The traps contained a natural attractant (a pine twig), artificial attractants based on natural compounds (alpha-pinene, turpentine oil, and ethanol), or a commercially available aggregation pheromone (Hylodor). 


\section{Materials and Methods}

\subsection{Localities}

The experiment was conducted in Norway spruce (Picea abies (L.) Karst) forests at four localities in the Czech Republic and at two localities in Slovakia (Figure 1). Norway spruce represented at least $90 \%$ of the trees (Table 1 ).

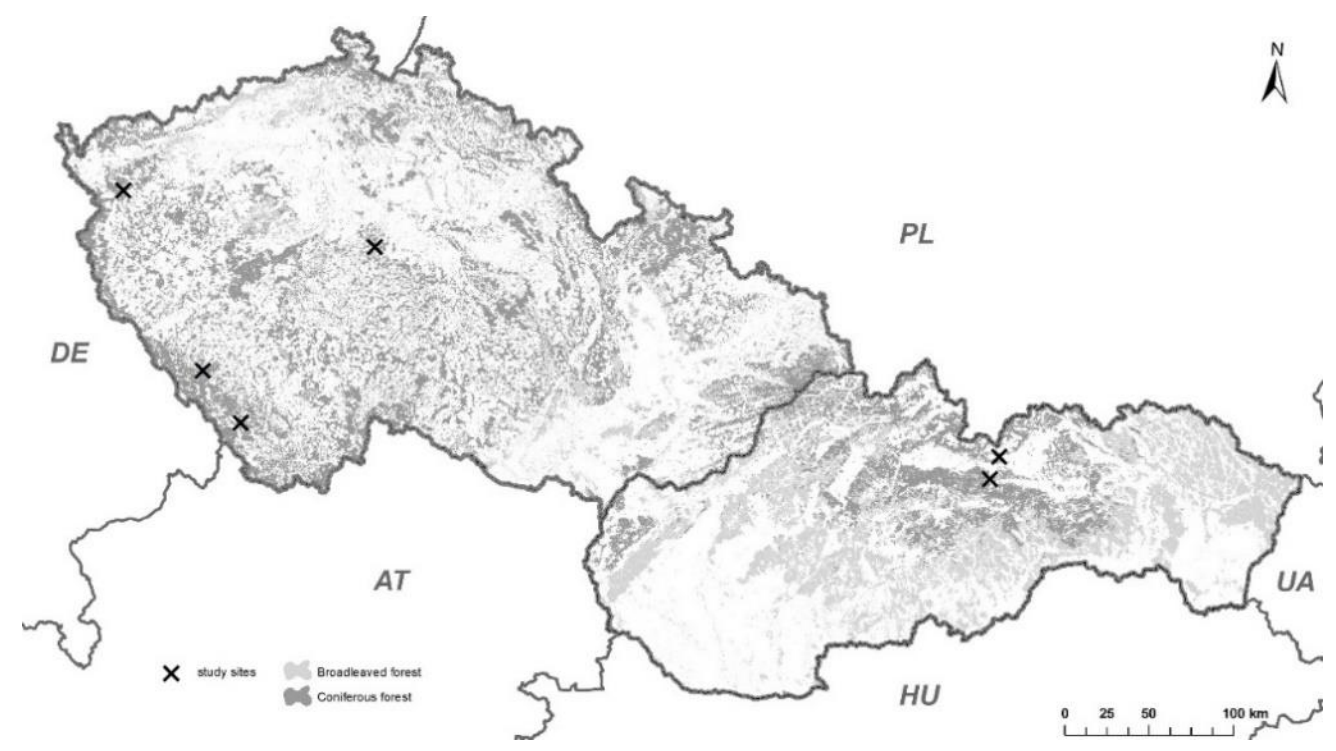

Figure 1. The six localities in the Czech Republic and Slovakia used in the current study.

Table 1. Description of study localities.

\begin{tabular}{|c|c|c|c|c|c|c|}
\hline Country/Locality & Geographical Coordinates & Area (ha) & Altitude & Aspect & Establishment of Cleared Area & Spruce Share (\%) \\
\hline CZ/Arnoštov & $\begin{array}{l}48.8890528 \mathrm{~N} \\
13.9529108 \mathrm{E}\end{array}$ & 0.74 & $944-946$ & Southeast & Felling September 2017 & 95 \\
\hline SK/Vyšné Hágy & $\begin{array}{l}49.120814 \mathrm{~N} \\
20.102610 \mathrm{E}\end{array}$ & 21.5 & $1216-1220$ & South & Wind-throw May 2014 & 95 \\
\hline CZ/Kašperské Hory & $\begin{array}{l}49.1343394 \mathrm{~N} \\
13.5876222 \mathrm{E}\end{array}$ & 0.81 & $780-785$ & Southwest & Felling October 2017 & 100 \\
\hline CZ/Kostelec n. Č. L & $\begin{array}{l}49.9198067 \mathrm{~N} \\
14.840943 \mathrm{E}\end{array}$ & 0.62 & $402-404$ & South & Felling December 2017 & 90 \\
\hline $\begin{array}{l}\text { SK/Liptovská } \\
\text { Teplička }\end{array}$ & $\begin{array}{l}48.995592 \mathrm{~N} \\
20.038704 \mathrm{E}\end{array}$ & 10.4 & $1115-1127$ & North & $\begin{array}{l}\text { Bark-beetle disturbance } \\
\text { February } 2018\end{array}$ & 100 \\
\hline CZ/Mariánske Lázně & $\begin{array}{l}50.0246936 \mathrm{~N} \\
12.7173419 \mathrm{E}\end{array}$ & 0.45 & $819-820$ & Plane & $\begin{array}{l}\text { Bark-beetle disturbance May } \\
2017\end{array}$ & 100 \\
\hline
\end{tabular}

The trees at the locality had been removed for felling (harvest) or because of wind damage or bark beetle outbreak (Table 1). After the trees were removed, there were about 400 stumps per ha.

\subsection{Attractants and Evaporators}

Pine twigs and four chemical attractants were tested. All twigs (50 mm long and $12 \pm 2 \mathrm{~mm}$ in diameter) were cut from a single 50-year-old Pinus sylvestris (L.) tree on 10 April 2018. The age of the twigs was 4-6 year. The twigs were stored in hermetically sealed polyethylene bags at $-20{ }^{\circ} \mathrm{C}$. One thawed twig was placed per trap, and a 20-mL bottle containing ethyl alcohol was placed next to the twig. The lid of the bottle had six holes with a diameter of $2 \mathrm{~mm}$ and one hole with a diameter of $4 \mathrm{~mm}$; a polypropylene string that was attached to the larger hole and to the trap rim was used to suspend the bottle in the trap.

Four kinds of evaporators were used to disperse the chemical attractants. One of these was the Hylodor (A) (Z.D. Chemipan), which is a commercially available evaporator plus attractant (a mixture of organic and inorganic substances) produced in Poland (Table 2). The other type of evaporator consisted of a polypropylene tube fabricated by the Fytofarm Ltd. Co. (Bratislava, Slovakia) 
(Table 2). The polypropylene tubes were used for the other three kinds of attractants and the control. After the tubes were filled, they were head sealed, and the content was released only through the polypropylene walls.

Table 2. Descriptions of the attractants.

\begin{tabular}{|c|c|c|c|}
\hline Attractant & Daily Vapour (g)** & Attractant Composition & Ratio of Components \\
\hline A-Hylodor & 0.012 & mixture of organic and inorganic substances & - \\
\hline B-alpha-pinene + ethanol * & 0.070 & $\begin{array}{c}\text { mixture of alpha-pinene } \\
\text { (1R)-(+)-alpha-pinene (98\%) CAS7785-70-8, } \\
\text { EINECS: } 232087-8 \text { + ethanol CAS: } 64-17-5, \\
\text { EINECS: } 200-578-6\end{array}$ & $1: 2^{* * *}$ \\
\hline $\begin{array}{l}\text { C-Turpentine oil + ethanol } \\
\text { separated * }\end{array}$ & $\begin{array}{l}\text { 1st tube: } 0.023 \\
\text { 2nd tube: } 0.241\end{array}$ & $\begin{array}{l}\text { 1st tube: ethanol CAS: } 64-17-5, \text { EINECS: } \\
\text { 200-578-6 } \\
\text { 2nd tube: turpentine, oil CAS: 7785-70-8, } \\
\text { EINECS: } 232087-8\end{array}$ & $\begin{array}{l}100 \% \\
100 \%\end{array}$ \\
\hline D-Turpentine oil + ethanol * & 0.093 & $\begin{array}{c}\text { mixture: turpentine, oil CAS: 7785-70-8, } \\
\text { EINECS: } 232087-8 \text { + ethanol CAS: } 64-17-5 \text {, } \\
\text { EINECS: } 200-578-6\end{array}$ & $2: 1 * * * *$ \\
\hline $\begin{array}{c}\text { PC-pine branch + ethanol } \\
\text { in a bottle }\end{array}$ & 0.402 & ethanol CAS: 64-17-5, EINECS: 200-578-6 & - \\
\hline
\end{tabular}

* The evaporators for these attractants were polypropylene tubes (diameter $=23 \mathrm{~mm}$, height $=49 \mathrm{~mm}$, volume $=$ $12.5 \mathrm{ml}$, weight without attractant $=3.5$ to $4.0 \mathrm{~g}$ ). Each tube contained $6 \mathrm{~mL}$ of attractant. ${ }^{* *}$ Vapour in the laboratory condition at $19.54 \pm 1.73{ }^{\circ} \mathrm{C}, 36.53 \pm 3.12 \%{ }^{* * *}$ Used according to [33]; ${ }^{* * *}$ Used according to [29].

\subsection{Pitfall Traps and Experimental Design}

Pitfall traps consisted of 1.2-litre buckets with 10 holes (10 $\mathrm{mm}$ in diameter) in the upper part of the trap (Figure 2). The traps had lids and were buried in the ground so that the holes, through which beetles could pass, were at the soil surface. The bottom of each trap contained $200 \mathrm{~mL}$ of propylene glycol (CAS: 57-55-6, EINECS: 200-338-0) mixed with water (1:1 ratio) and Tween 80 wetting agent (Carl Roth, CAS 9005-65-6), which killed and preserved the beetles that fell into the trap. One evaporator, in which the attractant was placed, was also hung from the upper rim of each trap so that it rested along the inner wall of the trap and above the propylene glycol-water mixture.
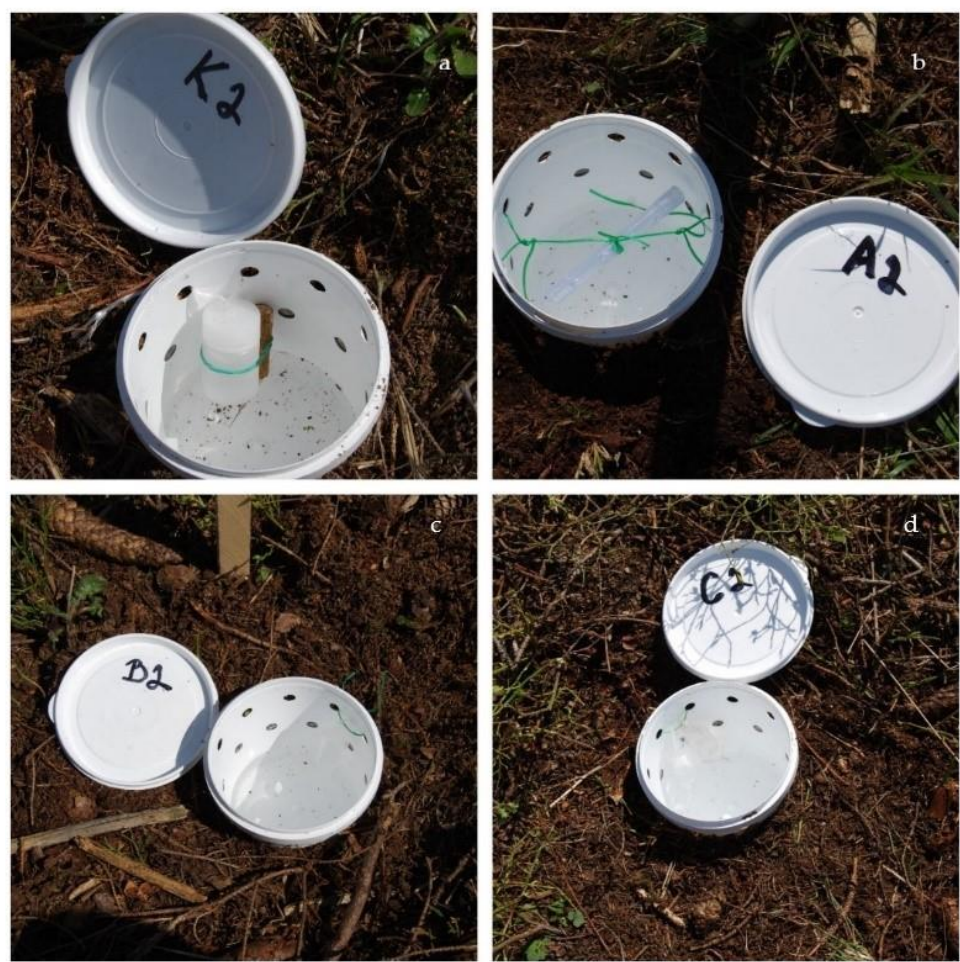

Figure 2. Photographs of representative pitfall traps and different type lure (a-d). 
A total of 36 pitfall traps were placed in one plot $(22.0 \mathrm{~m} \times 28.5 \mathrm{~m})$ at each locality. The distance between the traps was 5-6 m depending on the obstacles in the field. Among the 36 traps in each plot, 24 contained chemical attractants, 6 contained one pine twig + ethanol in a bottle, and 6 were without any attractant and served as negative control. The traps were distributed in the plot so that a specific type of attractant was not located near the same attractant type (Figure 3).

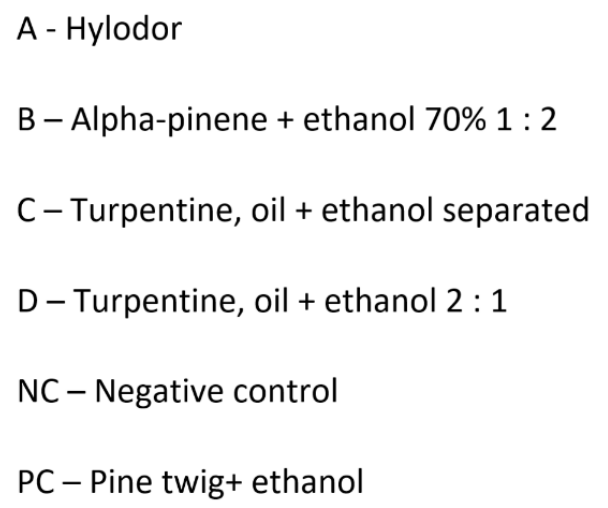

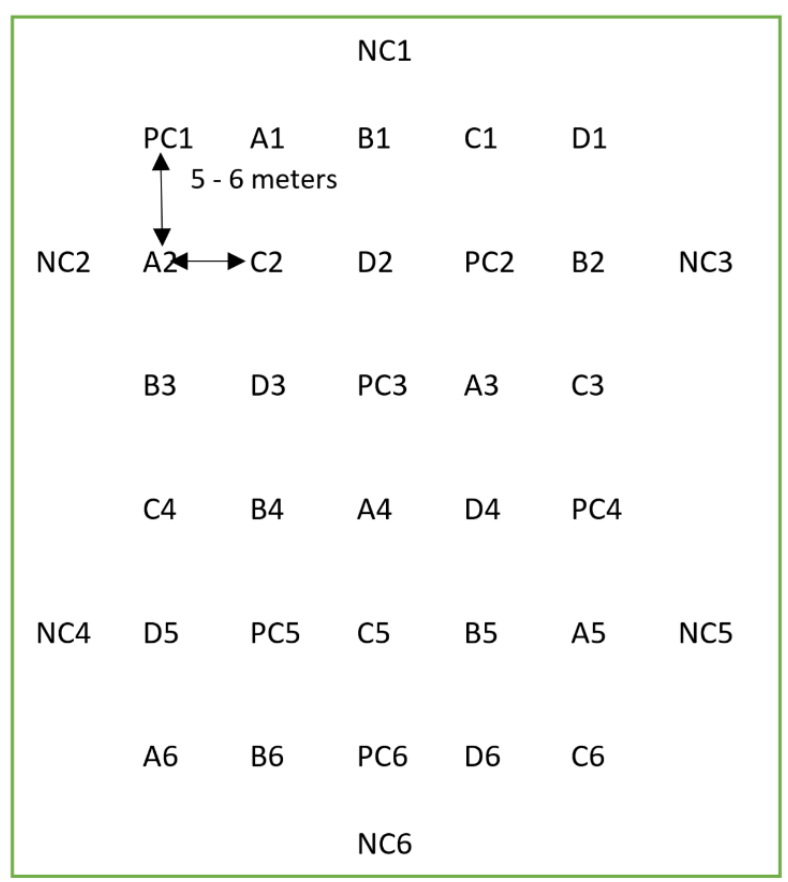

Figure 3. Locations of the pitfall traps in a plot (the attractant is indicated by the letters, and the trap replicate is indicated by the number).

The experiment began on 13 April 2018 and ended on 31 August 2018. Traps were checked every week at each plot on the same day of the week; all trapped beetles were removed and counted according to species and sex. For traps with twigs, twigs were replaced, and fresh ethanol was added to the bottles every week. For traps with synthetic attractants, the attractants were replaced during the 8 th and 16th week of the experiment.

\subsection{Statistical Analyses}

The cumulative number of $H$. abietis adult males and adult females caught per trap across all trap types did not fit a normal distribution (Figure 4), and the data failed the test for homogeneity of variance concerning the effects of attractant and locality (Bartlett's K-squared $=206.72, \mathrm{df}=5$, $p$-value $\left.<0.001=2.2 \times 10^{-16}\right)$. As a consequence, the general linear model (GLM) rather than ANOVA was used. The complete model is presented in Appendix A.

The results of the GLM model were tested using ANOVA for detection of differences and their sizes among different treatments and localities. Statistical analyses were performed in R software (RStudio Version 1.1.423, (C) 2009-2018 RStudio, Inc., package lme4, version 1.1-19, Boston, MA, USA). 

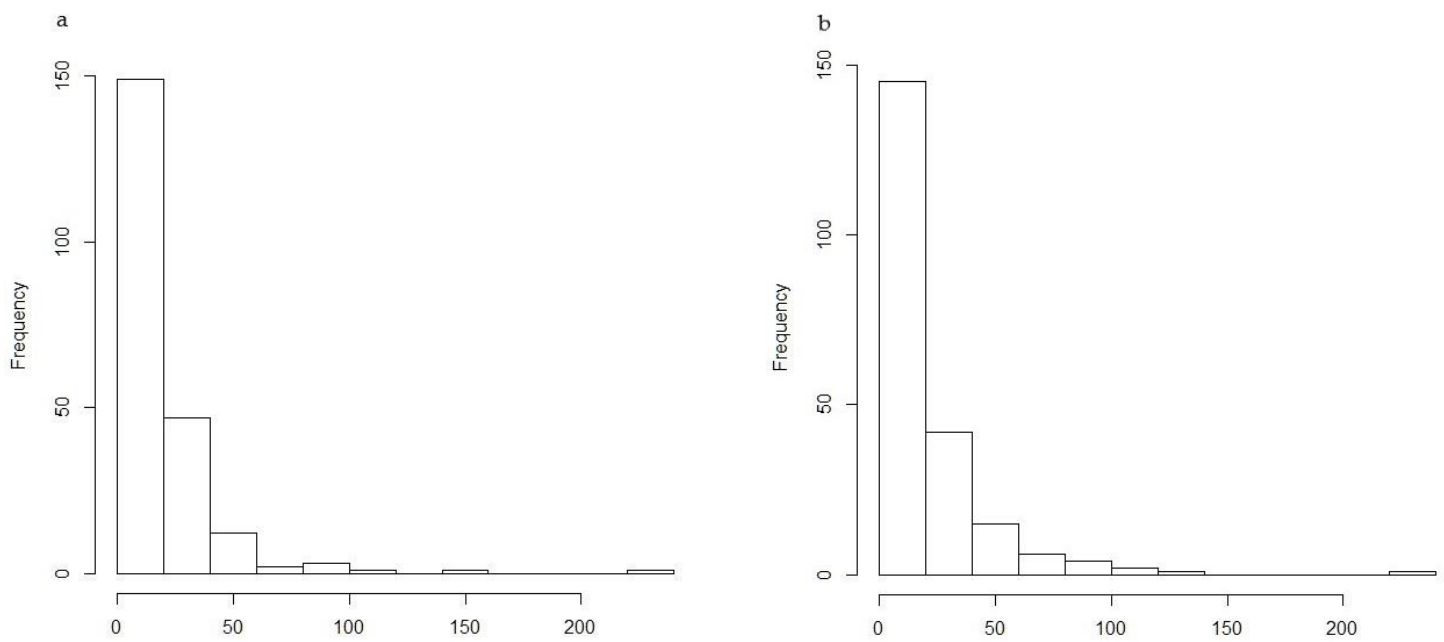

Figure 4. Frequency distribution of numbers of $H$. abietis adult males (a) and females (b) caught per trap across all attractant types.

\section{Results}

The main species captured in our pitfall traps were H. abietis and H. pinastri. In total, 8266 adults of $H$. abietis and 2040 adults of $H$. pinastri were caught in all pitfall traps at all localities. The number of $H$. abietis caught per locality and per attractant type was correlated with the number of $H$. pinastri caught per locality and per attractant type $\left(\mathrm{y}=10.08+0.20 \mathrm{x} ; \mathrm{r}=0.90 ; p=0.0000 ; r^{2}=0.81\right)$. The number of trapped adults (total of both species) was highest with a pine twig + ethanol (Table 3). Among the chemical attractants, the number of trapped adults (total of both species) was highest with alpha-pinene + ethanol followed by turpentine oil and ethanol (separated); the number was lowest with turpentine oil + ethanol (combined) (Table 3).

Table 3. Numbers of $H$. abietis/H. pinastri trapped as affected by locality and attractant.

\begin{tabular}{ccccccc}
\hline - & \multicolumn{6}{c}{ Attractant } \\
\hline Locality & Hylodor & $\begin{array}{c}\text { Alpha-Pinene }+ \\
\text { Ethanol }\end{array}$ & $\begin{array}{c}\text { Turpentine, Oil + } \\
\text { Ethanol Separated }\end{array}$ & $\begin{array}{c}\text { Turpentine, Oil + } \\
\text { Ethanol Combined }\end{array}$ & $\begin{array}{c}\text { Negative } \\
\text { Control }\end{array}$ & $\begin{array}{c}\text { Pine Twig + } \\
\text { Ethanol }\end{array}$ \\
\hline Arnoštov & $269 / 38$ & $405 / 74$ & $137 / 9$ & $102 / 2$ & $8 / 0$ & $681 / 144$ \\
Vyšné Hágy & $150 / 72$ & $265 / 96$ & $130 / 48$ & $59 / 9$ & $1 / 0$ & $449 / 185$ \\
Kašperské & 34,379 & $273 / 54$ & $205 / 63$ & $205 / 76$ & $23 / 0$ & $656 / 202$ \\
$\begin{array}{c}\text { Hory } \\
\text { Kostelec n. Č.L } \\
\text { Liptovská } \\
\text { Teplička } \\
\text { Mariánské } \\
\text { Lázně }\end{array}$ & $228 / 72$ & $286 / 65$ & $200 / 51$ & $139 / 37$ & $0 / 0$ & $367 / 95$ \\
\hline Total & $456 / 88$ & $416 / 80$ & $103 / 18$ & $137 / 35$ & $9 / 0$ & $1310 / 226$ \\
\hline & $1480 / 356$ & $1692 / 387$ & $32 / 10$ & $22 / 18$ & $2 / 0$ & $117 / 69$ \\
\hline
\end{tabular}

The H. abietis sex ratio differed among localities. Two localities had a 50:50 sex ratio, two had more males than females, and two had more females than males (Table 4). Across all localities, the average number of adults trapped per ha was $>14,000$ for $H$. abietis and $>3000$ for H. pinastri (Table 4). The number of $H$. abietis adults trapped per ha significantly differed among localities and was highest at Liptovská Teplička and lowest at Mariánské Lázně (Table 4). 
Table 4. Numbers of H. abietis males and females and H. pinastri (both sexes) trapped at individual localities (* average).

\begin{tabular}{|c|c|c|c|c|c|c|c|}
\hline Locality & $\begin{array}{c}\text { Number of } \\
\text { H. abietis } \\
\text { Males Trapped }\end{array}$ & $\begin{array}{c}\text { Number of } \\
\text { H. abietis } \\
\text { Females } \\
\text { Trapped }\end{array}$ & $\begin{array}{l}\text { Sex Ratio of } \\
\text { Trapped } \\
\text { Males:Females }\end{array}$ & $\begin{array}{l}\text { Total Number } \\
\text { of } H . \text { abietis } \\
\text { Trapped }\end{array}$ & $\begin{array}{l}\text { Number of } \\
\text { H. abietis } \\
\text { Trapped/Ha }\end{array}$ & $\begin{array}{c}\text { Number of } \\
\text { H. pinastri } \\
\text { Trapped }\end{array}$ & $\begin{array}{c}\text { Number of } \\
\text { H. pinastri } \\
\text { Trapped/Ha }\end{array}$ \\
\hline Vyšné Hágy & 456 & 598 & $43: 57$ & 1054 & 10,910 & 411 & 4255 \\
\hline Kašperské Hory & 979 & 726 & $57: 43$ & 1705 & 17,650 & 474 & 4907 \\
\hline Kostelec n. Č.L. & 610 & 610 & $50: 50$ & 1220 & 12,630 & 320 & 3313 \\
\hline Liptovská Teplička & 1212 & 1219 & $50: 50$ & 2431 & 25,165 & 447 & 4627 \\
\hline
\end{tabular}

The numbers of trapped individuals significantly differed among localities and attractants (Figures 5 and 6 and Appendix A). Trapping was highest with a pine twig \pm ethanol. Trapping was generally similar with Hylodor and alpha-pinene + ethanol but was higher with Hylodor at some localities (Kašperské Hory, Liptovská Teplička) and was higher with alpha-pinene + ethanol at other localities (Arnoštov, Vyšné Hágy, Kostelec n. Č.L., Mariánské Lázně). Trapping was significantly lower with turpentine oil + ethanol (separated) and with turpentine oil + ethanol (combined) than with a pine twig \pm ethanol, Hylodor, or alpha-pinene + ethanol.
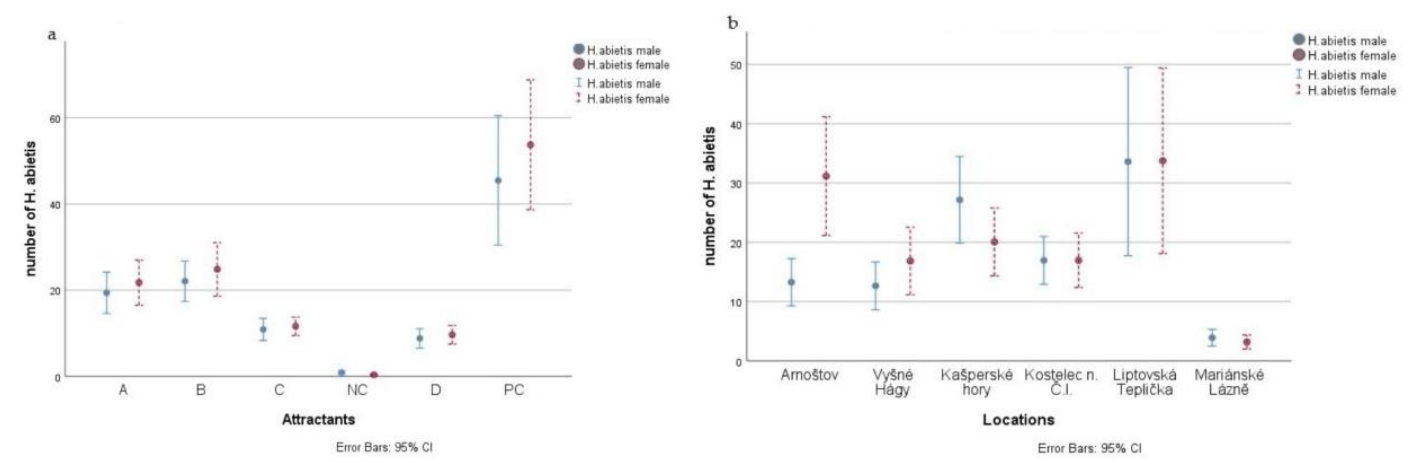

Figure 5. Number (mean $\pm \mathrm{SE}$ ) of $H$. abietis trapped with individual attractants across all localities (a) and at individual localities across all attractant treatments including the control (b) (for attractant abbreviations, see Figure 1).

At all localities, trapping was highest at the beginning of May and then gradually decreased (Figure 6). At the end of the experiment, only a few individuals were trapped at each locality (Figure 6).

Pairwise comparisons were made of the efficacy of attractants in trapping H. abietis (based on the number of individuals by sex trapped across all localities) (Tables 5 and 6). Almost all pairs were statistically different. For both males and females, trapping was always highest with a pine twig with ethanol and was always lowest with the no attractant control. Trapping did not significantly differ between turpentine oil + ethanol (separated) vs. turpentine oil + ethanol (combined) for both males and females or between turpentine oil + ethanol (separated) vs. Hylodor for males. 


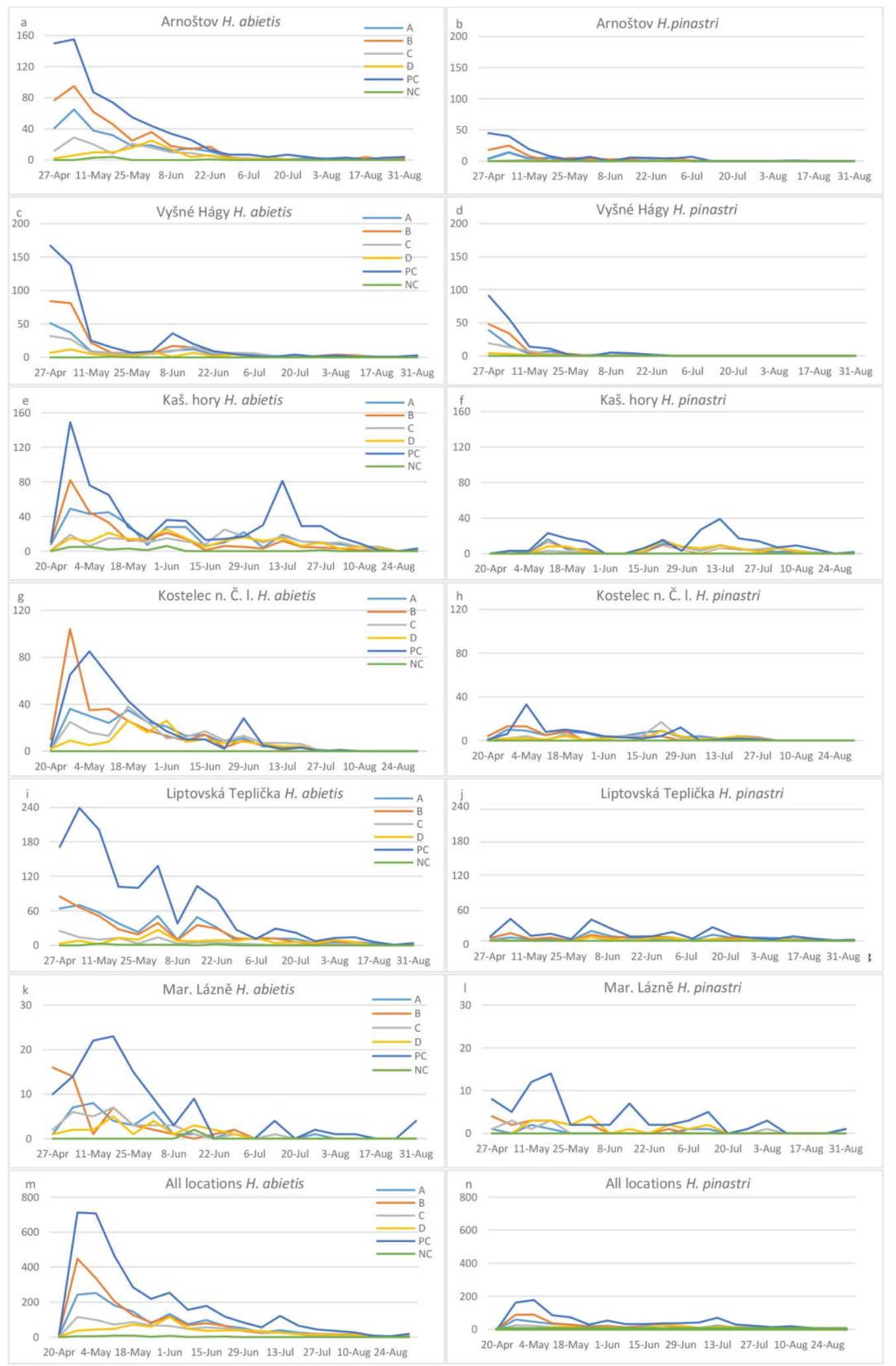

Figure 6. Mean numbers of $H$. abietis $(\mathbf{a}, \mathbf{c}, \mathbf{e}, \mathbf{g}, \mathbf{i}, \mathbf{k}, \mathbf{m})$ and $H$. pinastri $(\mathbf{b}, \mathbf{d}, \mathbf{h}, \mathbf{j}, \mathbf{l}, \mathbf{n})$ adults trapped over time as affected by attractant and locality. 
Table 5. Pairwise comparison of attractant efficacy in trapping male H. abietis (based on number of individuals trapped across all localities).

\begin{tabular}{ccccc}
\hline Attractant Pair & Absolute Difference & Standard Error & $z$-Value & $p$-Value \\
\hline B-A & 0.4400 & 0.1471 & 2.991 & $<0.02791^{*}$ \\
C-A & -0.4595 & 0.1844 & -2.492 & $0.10974^{*}$ \\
NC-A & -2.5390 & 0.4241 & -5.987 & $<0.001^{* * *}$ \\
D-A & -0.7198 & 0.2005 & -3.591 & $<0.00368^{* *}$ \\
PC-A & 0.9268 & 0.1355 & 6.838 & $<0.001^{* * *}$ \\
C-B & -0.8995 & 0.1712 & -5.254 & $<0.001^{* * *}$ \\
NC-B & -2.9789 & 0.4185 & -7.118 & $<0.001^{* * *}$ \\
D-B & -1.1598 & 0.1884 & -6.155 & $<0.001^{* * *}$ \\
PC-B & 0.4868 & 0.1170 & 4.162 & $<0.001^{* * *}$ \\
NC-C & -2.0794 & 0.4330 & -4.802 & $<0.001^{* * *}$ \\
D-C & -0.2603 & 0.2188 & -1.190 & $0.82316^{*}$ \\
PC-C & 1.3863 & 0.1614 & 8.591 & $<0.0011^{* * *}$ \\
D-NC & 1.8192 & 0.1614 & 4.133 & $<0.001^{* * *}$ \\
PC-NC & 3.4657 & 0.4146 & 8.360 & $<0.0011^{* * *}$ \\
PC-D & 1.6466 & 0.1795 & 9.171 & $<0.0011^{* * *}$ \\
\hline
\end{tabular}

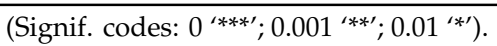

Table 6. Pairwise comparison of attractant efficacy in trapping female H. abietis (based on number of individuals trapped across all localities).

\begin{tabular}{ccccc}
\hline Attractant Pair & Absolute Difference & Standard Error & $z$-Value & $p$-Value \\
\hline B-A & 0.39330 & 0.09315 & 4.222 & $<0.001^{* * *}$ \\
C-A & -0.77405 & 0.12813 & -6.041 & $<0.001^{* * *}$ \\
NC-A & -4.56954 & 0.71076 & -6.429 & $<0.001^{* * *}$ \\
D-A & -1.08830 & 0.14341 & -7.589 & $<0.001^{* * *}$ \\
PC-A & 0.92557 & 0.08506 & 10.882 & $<0.001^{* * *}$ \\
C-B & -1.16736 & 0.12138 & -9.618 & $<0.001^{* * *}$ \\
NC-B & -4.96284 & 0.70957 & -6.994 & $<0.001^{* * *}$ \\
D-B & -1.48160 & 0.13741 & -10.782 & $<0.001^{* * *}$ \\
PC-B & 0.53227 & 0.07450 & 7.145 & $<0.001^{* * *}$ \\
NC-C & -3.79549 & 0.71501 & -5.308 & $<0.001^{* * *}$ \\
D-C & -0.31425 & 0.16316 & -1.926 & 0.337 \\
PC-C & 1.69963 & 0.11528 & 14.744 & $<0.001^{* * *}$ \\
D-NC & 3.48124 & 0.71790 & 4.849 & $<0.001^{* * *}$ \\
PC-NC & 5.49512 & 0.70856 & 7.755 & $<0.001^{* * *}$ \\
PC-D & 2.01388 & 0.13205 & 15.251 & $<0.001^{* * *}$ \\
\hline
\end{tabular}

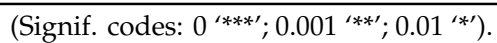

\section{Discussion}

During the growing season of 2018, we recorded the capture of H. abietis in pitfall traps deployed in recently cleared spruce stands in six Central European localities where altitudes ranged from 400 to $1220 \mathrm{~m}$ a.s.l. The large-scale experiment (covering an area of $550 \mathrm{~km} \times 200 \mathrm{~km}$ ) was performed in two countries (Figure 1). Buckets of 1.2-litre were used as traps with 10-mm-diameter entrance holes (Figure 2). These pitfall traps were easy to construct and deploy. However, pitfall traps are not selective, even with use of entrance holes. They can also catch other invertebrates, but impact is weak [31]. They have to be expose only for necessary period and have not be forgotten in forests [40].

All of the attractants in our experiment showed some ability to attract $H$. abietis and $H$. pinastri. H. abietis is very abundant in Central Europe [3]. H. pinastri is also common [4,41-44] but is less abundant than H. abietis [45-47]. We assume that fewer H. pinastri than H. abietis were attracted to pitfall traps with pine twigs because $H$. pinastri prefers spruce [48] while $H$. abietis prefers pine [49].

For H. abietis, trapping was always highest with a pine twig with ethanol. It should be recognized that daily vapours of studied attractants are low in comparison with published data $[33,35,36]$. Experimental evaporators have comparable vaporization as manufactured Hylodor. Ref. [33] had higher vapour, but used attractants that in the bottle and filter paper. This method is not used in practice. We wanted to test the methods usable for forest practice and easy to use. For foresters, 
the industrially produced evaporators are the best. Therefore, we used Hylodor and other types of evaporator consisting of a polypropylene tube manufactured by Fytofarm Ltd. Co. The thermoplastic material used ensures regular evaporation for as long as possible [50].

Natural materials (trap barks) for attracting H. abietis began to be used in the first half of 19th century [22] and were frequently used by the beginning of the 20th century [1]. A disadvantage of trap barks is the need for their frequent replacement (once every 2 weeks), and the need to remove the attracted H. abietis adults every $2-5$ days. Another disadvantage of trap barks is their high price, which in Slovakia is about $3.5 €$ for one piece of bark [51]. For monitoring, about 25 pieces of trap bark/ha are needed. The price of such monitoring (excluding the maintenance costs) would be $175 € /$ ha per month. In contrast to trap barks, pitfall traps do not require regular visits. During our experiment, we emptied them once per week, but only one inspection per month would be needed if attractants in tubes were used. The alpha-pinene + ethanol attractant costs $2.5 €$ per trap and can last for 6- 8 weeks, and the cost of one bucket used for the pitfall trap is $0.33 €$. In this case, the costs excluding maintenance costs are $70.75 €$ with 25 pitfall traps/ha.

There are additional problems with the use of trap barks and other natural materials as pest attractants [33]. The types of natural materials used to attract pests can differ in their monoterpene content $[52,53]$. Another problem is that wooden attractants dry, which gradually reduces their attractiveness [45]. When pests attack wooden attractants, they feed on them and disturb the material. This increases the release of compounds that attract H. abietis [32] but decreases the longevity of the attractant. As a consequence, we replaced the pine twigs in our experiment every week. [31], who used source spruce twig replaced it also each week. Although we do not know anything about population densities in their study areas, they caught $10 x$ less beetles in comparison with our results [31].

The second most effective attractant in the current study was alpha-pinene, which is present in conifers and has a resin-like odour. This compound is usual in that its content within a tree species is constant regardless [54]. The ratio of fragrant compounds in coniferous species is largely genetically driven and is not affected by other factors [55]. In the evaporator, alpha-pinene was mixed with ethanol, because such a combination is six times more attractive to $H$. abietis than alpha-pinene alone, and 10 times more attractive than ethanol alone [33]. In addition, the effect of the combination in the field is synergistic [32].

The third most successful attractant was the commercially available Hylodor. This attractant, which is produced in Poland, is described as an aggregation pheromone, but its composition is unknown. Kuźmiński and Bilon [30] showed that the number of beetles trapped was only slightly higher with Hylodor than with logs or wooden discs.

The fourth highest number of catches was obtained when turpentine oil and $70 \%$ ethanol were placed in separate tubes. Turpentine oil is extracted from resin by distillation and contains mainly alpha-pinene and beta pinene [29]. Although this lure has a low price [31,56], it trapped only low numbers of Hylobius spp. adults in the current study. The last attractant that was used in this study was turpentine oil mixed with ethanol in a 2:1 ratio. This attractant also trapped only a low number of Hylobius spp. adults. The concentration of turpentine oil and ethanol used in our experiment was equal to that used by [29]. We suspect that such a strong concentration could repel rather than attract, and that a smaller proportion of turpentine might be more effective [56].

The negative control (without attractant) pitfall traps in the current study trapped only a few individuals, which probably were not attracted to the traps but simply entered them accidently. The small number of beetles captured in these traps confirms that the propylene glycol:water mixture used to kill and preserve the trapped beetles did not function as an attractant or as a repellent, and did not therefore influence the trapping of $H$. abietis [56].

In total, we captured 8266 adults of $H$. abietis and 2040 adults of $H$. pinastri at six localities. Ref. [57] stated that a trap can attract adults from a distance of $2.5 \mathrm{~m}$ in all directions. In this study, we found that regardless of the lure used, a pitfall trap can attract adults at distances greater than $2.5 \mathrm{~m}$. With a trap situated at the edge of the plot, we caught on average $290 \pm 203$ adults of H. abietis and $74 \pm 52$ 
adults of $H$. pinastri. In centrally located traps, we caught on average $250 \pm 156$ and $59 \pm 41$ adults of $H$. abietis and $H$. pinastri per trap, respectively. If we assume that each trap in a plot can capture beetles within a 3-m radius with baited traps (approximately $600 \mathrm{~m}^{2}$ ), we will get an "H. abietis trapping area" of approximately $28.0 \times 34.5 \mathrm{~m}\left(966 \mathrm{~m}^{2}\right)$. When we calculated the number of catches per ha, we found several thousand to several tens of thousands of $H$. abietis adults per ha and thousands of $H$. pinastri adults per ha depending on the locality (Table 4). In most localities, we found more than 10,000 beetles per ha; i.e., the density of $H$. abietis coincided with that stated by [58] (10,000-18,000 adults/ha). Other authors have also indicated that $H$. abietis numbered about 10,000/ha [36,59], and [4] found that $H$. abietis numbers exceeded 14,000/ha at three localities. We therefore assume that we caught the majority of the local population of $H$. abietis as well as of $H$. pinastri. This is also supported by the fact that in the second half of the summer, we did not catch any beetles, although the adults of new generation, which have a flight at the autumn, should be caught [60].

Clearcutting is almost always performed in autumn or winter, and the remaining stumps are surrounded by older stands. Larvae develop on the roots of fresh pine or spruce stumps and exceptionally also on the roots of 1-year-old stumps [54]. At mid-elevations in Central Europe, stumps older than 1 year are not attractive (personal observation Holuša, Galko, Lalík) [24]. This is also the reason why the number of beetles caught was the least at the locality Mariánské Lázně (the original forest was cut in May of previous year). In Scandinavia, stumps can remain attractive for 3 years [27], which was confirmed at the Vyšné Hágy locality, which is 1216-1220 m a.s.l., where the stumps were 4 years old, and the beetle was still abundant in the cleared area (personal observation). It is clear that beetles trapped in cleared areas could have originated from the surrounding areas. To select suitable localities, $H$. abietis adults use their olfactory sensors at the base of their antennae. At longer distances, adults orientate according to attractants produced by host tree species [61,62]. On clear cuttings, they probably distinguish shape of seedlings and older trees while flying [63]. At short distances, they react to pheromones [64]; male pheromones cause adults to aggregate, and female pheromones attract males [65]. The females can crawl or fly considerable distances to locate oviposition sites [66]. H. abietis can fly up to $2000 \mathrm{~m}$ in a single event, and can fly more than 80,000 $\mathrm{m}$ over their entire life [67].

Over the entire experiment, we caught 4389 females and 3877 males of $H$. abietis. Based on these values, the overall female:male sex ratio was 53:47, although males were more abundant than females at some plots. [32], who used pitfall traps baited with three types of attractants (alpha-pinene, ethanol, and a combination of these two) reported an $\mathrm{H}$. abietis sex ratio similar to that in our study; the number of females was greater than the number of males irrespective of the combination of lures.

\section{Conclusions}

Forestry managers use monitoring data of $H$. abietis to plan methods for reducing the damage on plants. In the case of critical numbers exceeded the feeding barriers or insecticides are applied. The results show that pine weevil populations can be monitored using minimally modified buckets as pitfall traps. The cost of such traps is low, and the installation is simple. A natural material, namely a pine twig (+ ethanol), was the most successful attractant, which was consistent with previous reports. The pine twig + ethanol attractant is easy to prepare and is substantially cheaper than artificial attractants. Replacement of the twig after 1 week eliminates eventual shifts in the composition of volatile compounds, and the replacement of the twig every 2 weeks may be sufficient. During the replacement of twigs and the refilling of ethanol, trapped adults are removed from the trap to avoid attracting carrion beetles. When performed by a two-member team, the replacement required about 20 min per locality. On a per ha basis, the inspection of all traps installed (i.e., 300 traps/ha) would require about $3 \mathrm{~h}$. From a practical point of view, the number of traps can be reduced, because traps at the edge caught more beetles, and the distance between the traps could probably be increased to 10-20 $\mathrm{m}$, i.e., trap density could probably be reduced to 50-100 traps/ha. The results also suggest that pitfall traps with pine twigs + ethanol might be used for mass trapping. Such mass trapping would be very simple and based on our results all beetles could be trapped during period of April to June. This is 
especially attractive because the use of chemical insecticides is increasingly restricted in the Europe. As noted earlier, the monitoring and mass trapping of H. abietis is substantially cheaper with pitfall traps than with trap barks.

Author Contributions: Data curation, M.L., K.R. and J.H.; Formal analysis, P.S.; Methodology, M.L., J.G., A.K., C.N., S.M.; Writing—original draft, M.L., J.G. and J.H.; Writing—review and editing, M.L. and J.H.

Funding: This work was supported by the Slovak Research and Development Agency under the contract No. APVV-16-0031, APVV-18-0086 and by the Ministry of Agriculture and Rural Development of the Slovak Republic based on the item No. 08V0301. This work was also supported by the Czech University of Life Sciences Prague project No. IGA C_01_18 and by the grant "Advanced research supporting the forestry and wood-processing sector's adaptation to global change and the 4th industrial revolution", No. CZ.02.1.01/0.0/0.0/16_019/0000803 financed by OP RDE.

Acknowledgments: The authors thank Bruce Jaffee (USA) for editorial and linguistic improvement of manuscript, and Tomáš Holík, Jan Pešl, Tomáš Fiala, Nikola Bohatá, and Jana Kubov for support with field work.

Conflicts of Interest: The authors declare no conflict of interest.

\section{Appendix A}

glm (formula $=$ hAbietisMale $\sim$ atraktant $*$ lokalita, family $=$ "poisson")

Deviance Residuals:

$\begin{array}{lllll}\text { Min } & \text { QQ } & \text { Median } & \text { 3Q } & \text { Max } \\ -10.2299 & -1.1360 & -0.1412 & 0.8858 & 10.0012\end{array}$

Coefficients:

Table A1. Full GLM model of tested factors, locality and attractant, and their interactions.

\begin{tabular}{|c|c|c|c|c|}
\hline & Estimate & Std. & Error & $\mathrm{z}$ value $\operatorname{Pr}(>|z|)$ \\
\hline (Intercept) & $2.539 \times 10^{0}$ & $1.147 \times 10^{-1}$ & $2.2134 \times 10^{1}$ & $<2 \times 10^{-16}$ \\
\hline atraktantB & $4.400 \times 10^{-1}$ & $1.471 \times 10^{-1}$ & $2.991 \times 10^{0}$ & $2.778 \times 10^{-3}$ \\
\hline atraktantC & $-4.595 \times 10^{-1}$ & $1.844 \times 10^{-1}$ & $-2.492 \times 10^{0}$ & $1.2685 \times 10^{-2}$ \\
\hline atraktantCon. & $-2.539 \times 10^{0}$ & $4.241 \times 10^{-1}$ & $-5.987 \times 10^{0}$ & $2.13 \times 10^{-9}$ \\
\hline atraktantD & $-7.198 \times 10^{-1}$ & $2.005 \times 10^{-1}$ & $-3.591 \times 10^{0}$ & $3.30 \times 10^{-4}$ \\
\hline atraktantPC & $9.268 \times 10^{-1}$ & $1.355 \times 10^{-1}$ & $6.838 \times 10^{0}$ & $8.00 \times 10^{-12}$ \\
\hline lokalitaVyšné Hágy & $-2.532 \times 10^{-1}$ & $1.735 \times 10^{-1}$ & $-1.459 \times 10^{0}$ & $1.44503 \times 10^{-1}$ \\
\hline lokalitaKašperské hory & $9.775 \times 10^{-1}$ & $1.346 \times 10^{-1}$ & $7.264 \times 10^{0}$ & $3.75 \times 10^{-13}$ \\
\hline lokalitaKostelec n.C.l. & $5.213 \times 10^{-1}$ & $1.448 \times 10^{-1}$ & $3.600 \times 10^{0}$ & $3.18 \times 10^{-4}$ \\
\hline lokalitaLiptovská Teplička & $1.035 \times 10^{0}$ & $1.335 \times 10^{-1}$ & $7.753 \times 10^{0}$ & $8.99 \times 10^{-15}$ \\
\hline lokalitaMarianske lázne & $-1.386 \times 10^{0}$ & $2.565 \times 10^{-1}$ & $-5.405 \times 10^{0}$ & $6.49 \times 10^{-8}$ \\
\hline atraktantB:lokalitaVyšné Hágy & $2.616 \times 10^{-1}$ & $2.168 \times 10^{-1}$ & $1.207 \times 10^{0}$ & $2.27423 \times 10^{-1}$ \\
\hline atraktantC:lokalitaVyšné Hágy & $5.409 \times 10^{-1}$ & $2.580 \times 10^{-1}$ & $2.096 \times 10^{0}$ & $3.6046 \times 10^{-2}$ \\
\hline atraktantCon.:lokalitaVyšné Hágy & $-1.539 \times 10^{0}$ & $1.094 \times 10^{0}$ & $-1.406 \times 10^{0}$ & $1.59605 \times 10^{-1}$ \\
\hline atraktantD:lokalitaVyšné Hágy & $-6.189 \times 10^{-2}$ & $3.069 \times 10^{-1}$ & $-2.02 \times 10^{-1}$ & $8.40180 \times 10^{-1}$ \\
\hline atraktantPC:lokalitaVyšné Hágy & $2.161 \times 10^{-1}$ & $2.018 \times 10^{-1}$ & $1.071 \times 10^{0}$ & $2.84314 \times 10^{-1}$ \\
\hline atraktantB:lokalitaKašperské hory & $-5.949 \times 10^{-1}$ & $1.799 \times 10^{-1}$ & $-3.307 \times 10^{0}$ & $9.43 \times 10^{-4}$ \\
\hline atraktantC:lokalitaKašperské hory & $-9.515 \times 10^{-2}$ & $2.181 \times 10^{-1}$ & $-4.36 \times 10^{-1}$ & $6.62641 \times 10^{-1}$ \\
\hline atraktantCon.:lokalitaKašperské hory & $-1.302 \times 10^{-1}$ & $5.062 \times 10^{-1}$ & $-2.57 \times 10^{-1}$ & $7.96947 \times 10^{-1}$ \\
\hline atraktantD:lokalitaKašperské hory & $1.300 \times 10^{-1}$ & $2.325 \times 10^{-1}$ & $5.59 \times 10^{-1}$ & $5.75957 \times 10^{-1}$ \\
\hline atraktantPC:lokalitaKašperské hory & $-3.462 \times 10^{-1}$ & $1.615 \times 10^{-1}$ & $-2.143 \times 10^{0}$ & $3.2100 \times 10^{-2}$ \\
\hline atraktantB:lokalitaKostelec n.C.l. & $-3.867 \times 10^{-1}$ & $1.920 \times 10^{-1}$ & $-2.014 \times 10^{0}$ & $4.3966 \times 10^{-2}$ \\
\hline atraktantC:lokalitaKostelec n.C.1. & $2.709 \times 10^{-1}$ & $2.264 \times 10^{-1}$ & $1.197 \times 10^{0}$ & $2.31322 \times 10^{-1}$ \\
\hline atraktantCon.:IokalitaKostelec n.C.1. & $-1.582 \times 10^{1}$ & $5.208 \times 10^{2}$ & $-3.0 \times 10^{-2}$ & $9.75762 \times 10^{-1}$ \\
\hline atraktantD:lokalitaKostelec n.C.1. & $2.667 \times 10^{-2}$ & $2.522 \times 10^{-1}$ & $1.06 \times 10^{-1}$ & $9.15798 \times 10^{-1}$ \\
\hline atraktantPC:lokalitaKostelec n.C.1. & $-6.026 \times 10^{-1}$ & $1.784 \times 10^{-1}$ & $-3.378 \times 10^{0}$ & $7.30 \times 10^{-4}$ \\
\hline atraktantB:lokalitaLiptovská Teplička & $-3.988 \times 10^{-1}$ & $1.755 \times 10^{-1}$ & $-2.273 \times 10^{0}$ & $2.3056 \times 10^{-2}$ \\
\hline atraktantC:lokalitaLiptovská Teplička & $-1.078 \times 10^{0}$ & $2.458 \times 10^{-1}$ & $-4.385 \times 10^{0}$ & $1.16 \times 10^{-5}$ \\
\hline atraktantCon.:lokalitaLiptovská Teplička & $-7.476 \times 10^{-1}$ & $5.563 \times 10^{-1}$ & $-1.344 \times 10^{0}$ & $1.79030 \times 10^{-1}$ \\
\hline atraktantD:lokalitaLiptovská Teplička & $-5.353 \times 10^{-1}$ & $2.475 \times 10^{-1}$ & $-2.163 \times 10^{0}$ & $3.0552 \times 10^{-2}$ \\
\hline atraktantPC:lokalitaLiptovská Teplička & $1.965 \times 10^{-1}$ & $1.567 \times 10^{-1}$ & $1.254 \times 10^{0}$ & $2.09960 \times 10^{-1}$ \\
\hline atraktantB:lokalitaMarianske lázne & $8.855 \times 10^{-2}$ & $3.336 \times 10^{-1}$ & $-2.65 \times 10^{-1}$ & $7.90676 \times 10^{-1}$ \\
\hline atraktantC:lokalitaMarianske lázne & $-9.352 \times 10^{-15}$ & $4.123 \times 10^{-1}$ & $0 \times 10^{0}$ & $1.000000 \times 10^{0}$ \\
\hline atraktantCon.:lokalitaMarianske lázne & $2.877 \times 10^{-1}$ & $8.558 \times 10^{-1}$ & $3.36 \times 10^{-1}$ & $7.36764 \times 10^{-1}$ \\
\hline atraktantD:lokalitaMarianske lázne & $5.480 \times 10^{-1}$ & $3.941 \times 10^{-1}$ & $1.390 \times 10^{0}$ & $1.64403 \times 10^{-1}$ \\
\hline atraktantPC:lokalitaMarianske lázne & $2.877 \times 10^{-1}$ & $2.943 \times 10^{-1}$ & $9.77 \times 10^{-1}$ & $3.28344 \times 10^{-1}$ \\
\hline
\end{tabular}


Table A2. Significant factors and their interaction.

\begin{tabular}{|c|c|}
\hline (Intercept) & $* * *$ \\
\hline atraktantB & $* *$ \\
\hline atraktantC & * \\
\hline atraktantCon. & $* * *$ \\
\hline atraktantD & $* * *$ \\
\hline atraktantPC & $* * *$ \\
\hline lokalitaVyšné Hágy & - \\
\hline lokalitaKašperské hory & $* * *$ \\
\hline lokalitaKostelec n. C.l. & $* * *$ \\
\hline lokalitaLiptovská Teplička & $* * *$ \\
\hline lokalitaMarianske lázne & $* * *$ \\
\hline atraktantB:lokalitaVyšné Hágy & - \\
\hline atraktantC:lokalitaVyšné Hágy & * \\
\hline atraktantCon.:lokalitaVyšné Hágy & - \\
\hline atraktantD:lokalitaVyšné Hágy & - \\
\hline atraktantPC:lokalitaVyšné Hágy & - \\
\hline atraktantB:lokalitaKašperské hory & $* * *$ \\
\hline atraktantC:lokalitaKašperské hory & - \\
\hline atraktantCon.:lokalitaKašperské hory & - \\
\hline atraktantD:lokalitaKašperské hory & - \\
\hline atraktantPC:lokalitaKašperské hory & * \\
\hline atraktantB:lokalitaKostelec n. C.l. & * \\
\hline atraktantC:lokalitaKostelec n. C.l. & - \\
\hline atraktantCon.:lokalitaKostelec n. C.l. & - \\
\hline atraktantD:lokalitaKostelec n. C.l. & - \\
\hline atraktantPC:lokalitaKostelec n. C.l. & $* * *$ \\
\hline atraktantB:lokalitaLiptovská Teplička & * \\
\hline atraktantC:lokalitaLiptovská Teplička & $* * *$ \\
\hline atraktantCon.:lokalitaLiptovská Teplička & - \\
\hline atraktantD:lokalitaLiptovská Teplička & * \\
\hline atraktantPC:lokalitaLiptovská Teplička & - \\
\hline atraktantB:lokalitaMarianske lázne & - \\
\hline atraktantC:lokalitaMarianske lázne & - \\
\hline atraktantCon.:lokalitaMarianske lázne & - \\
\hline atraktantD:lokalitaMarianske lázne & - \\
\hline atraktantPC:lokalitaMarianske lázne & - \\
\hline
\end{tabular}

(Dispersion parameter for poisson family taken to be 1)

Null deviance: 4695.37 on 215 degrees of freedom

Residual deviance: 734.05 on 180 degrees of freedom

AIC: 1638.40

Number of Fisher Scoring iterations: 13

\section{References}

1. Escherich, K. Die Forstinsekten Mitteleuropas, 2nd ed.; Paul Parey: Berlin, Germany, 1923; p. 663.

2. Day, K.R.; Leather, S.R. Threats to forestry by insect pests in Europe. In Forests and Insects; Watt, A.D., Stork, N.E., Hunter, M.D., Eds.; Chapman \& Hall: London, UK, 1997; pp. 177-205.

3. Långstöm, B.; Day, K.R. Damage, control and management of weevil pests, especially Hylobius abietis. In Bark and Wood Boring Insects in Living Trees in Europe: A Synthesis; Lieutier, F., Day, K.R., Battisti, A., Grégoire, J.-C., Evans, H.F., Eds.; Springer: Dordrecht, The Netherlands, 2004; pp. 415-444.

4. Eidmann, H.H. Hylobius Schönh. In Die Forstschädlinge Europas, 2nd ed.; Schwenke, W.K., Ed.; Paul Parey: Hamburg/Berlin, Germany, 1974; pp. 275-293.

5. Lindström, A.; Hellqvist, C.; Gyldberg, B.; Långström, B.; Mattsson, A. Field performance of a protective collar against damage by Hylobius abietis. Scand. J. For. Res. 1986, 1, 3-15. [CrossRef] 
6. Eidmann, H.H.; von Sydow, F. Stockings for protection of containerised seedlings against pine weevil (Hylobius abietis L.) damage. Scand. J. For. Res. 1989, 4, 537-547. [CrossRef]

7. Hagner, M.; Jonsson, C. Survival after planting without soil preparation for pine and spruce seedlings protected from Hylobius abietis by physical and chemical shelters. Scand. J. For. Res. 1995, 10, 225-234. [CrossRef]

8. Eidmann, H.H.; Nordenhem, H.; Weslien, J. Physical protection of conifer seedlings against pine weevil feeding. Scand. J. For. Res. 1996, 11, 68-75. [CrossRef]

9. Zumr, V.; Stary, P. LATEX paint as an antifeedent against Hylobius abietis (L.) (Col., Curculionidae) on conifer seedlings. Anz. Schädl. Pflanzenschutz Umweltschutz 1995, 21, 42-43. [CrossRef]

10. Nordlander, G.; Nordenhem, H.; Hellqvist, C. A flexible sand coating (Conniflex) for the protection of conifer seedlings against damage by the pine weevil Hylobius abietis. Agric. For. Entomol. 2009, 11,91-100. [CrossRef]

11. Kvaae.no. Available online: http://kvaae.no/what/ (accessed on 15 May 2019).

12. Harte, J.; Holdren, C.; Schneider, R.; Shirley, C. Toxics A to Z, a Guide to Everyday Pollution Hazards; University of California: Oxford, UK, 1991; p. 478. ISBN 9780520072244.

13. Rattner, B.A. History of wildlife toxicology. Ecotoxicology 2007, 18, 773-783. [CrossRef]

14. Bradberry, S.M.; Cage, S.A.; Proudfoot, A.T.; Vale, J.A. Poisoning due to pyrethroids. Toxicol. Rev. 2005, 24, 93-106. [CrossRef]

15. Pszczolkowski, M.A.; Dobrowolski, M. Circadian dynamics of locomotor activity and deltamethrin susceptibility in the pine Weevil Hylobius abietis. Phytoparasitica 1999, 27, 19-25. [CrossRef]

16. Dobrowolski, M. The susceptibility of the large pine weevil (Hylobius abietis L.) to insecticides and the role of the oxidative metabolism in the developing of the pest resistance to DDT and pyrethroids. Folia For. Polon. 2000, 42, 83-94.

17. Lempérière, G.; Julien, J. Protection against the pine weevil-Efficiency of a carbosulfan-based systemic insecticide. Rev. For. Fr. 2003, 55, 129-140. [CrossRef]

18. Rose, D.; Matthews, G.A.; Leather, S.R. Sub-lethal responses of the large pine weevil, Hylobius abietis, to the pyrethroid insecticide lambda-cyhalothrin. Physiol. Entomol. 2006, 31, 316-327. [CrossRef]

19. Glovacka, B.; Lech, A.; Wilczynski, W. Application of deltamethrin for spraying or dipping to protect Scots pine seedlings againts Hylobius abietis L. and logs against Tomicus piniperda L. Ann. Sci. For. 1991, 48, 113-117. [CrossRef]

20. Torstensson, L.; Börjesson, E.; Arvidsson, B. Treatment of bare root spruce seedlings with permethrin against pine weevil before lifting. Scand. J. For. Res. 1999, 14, 408-415. [CrossRef]

21. Rose, D.; Matthews, G.A.; Leather, S.R. Recognition and avoidance of insecticide-treated Scots Pine (Pinus sylvestris) by Hylobius abietis (Coleoptera: Curculionidae): Implications for pest management strategies. Agric. For. Entomol. 2005, 7, 187-191. [CrossRef]

22. Ratzeburg, J.T.C. Die Forst- Insekten. Erster Teil-Die Käfer; 2 Auflage; Nicolai'sche Buchhandlung: Berlin, Germany, 1839; p. 247.

23. Pfeffer, A.; Horák, E.; Kudela, M.; Muller, J.; Novakova, E.; Stolina, M. Ochrana Lesư; Státní Zemědělské Nakladatelství: Praha, Czech Republic, 1961; p. 838.

24. Modlinger, R.; Knížek, M. Klikoroh borový Hylobius abietis (L.). Lesnická Pr. 2009, 88, 1-4.

25. Galko, J.; Gubka, A.; Vakula, J. Praktické Skúsenosti s Využitím Lapacích Kôr na Zníženie Škôd Spôsobených Tvrdoňom Smrekovým na Mladých Výsadbách Ihličnatých Drevín. In Aktuálne Problémy v Ochrane Lesa; Kunca, A., Nový Smokovec, S., Kunca, A., Eds.; Národné Lesnícke Centrum: Zvolen, Slovakia, 2012; pp. 60-64.

26. Galko, J.; Vakula, J.; Kunca, A.; Rell, S.; Gubka, A. Ochrana Lesa; Ochrana lesa proti tvrdoňom a lykokazom na sadeniciach; Úrad pre Normalizáciu, Metorologiu a Skúšobníctvo: Bratislava, Slovakia, STN 48 2714; 2016; p. 8.

27. Nordenhem, H. Age, sexual development, and seasonal occurrence of the pine weevil Hylobius abietis. J. Appl. Entomol. 1989, 108, 260-270. [CrossRef]

28. Skłodowski, J.J.W.; Gadziński, J. Effectiveness of beetle catches in two types of traps for Hylobius abietis L. Sylwan 2001, 6, 55-63.

29. Moreira, X.; Costas, R.; Sampedro, L.; Zas, R. A simple method for trapping Hylobius abietis (L.) alive in northern Spain. For. Syst. 2008, 17, 188-192. [CrossRef] 
30. Kuźmiński, R.; Bilon, A. Evaluation of effectiveness of selected types of traps used in capturing of large pine weevil-Hylobius abietis (L.). Acta Sci. Pol.-Silv. Colendarum R. Ind. Lig. 2009, 8, 19-26.

31. Zumr, V.; Stary, P.P. Field experiments with different attractants in baited pitfall traps for Hylobius abietis L. (Col., Curculionidae). J. Appl. Entomol. 1992, 113, 451-455. [CrossRef]

32. Tilles, D.A.; Sjödin, K.; Nordlander, G.; Eidmen, H.H. Synergism between ethanol and conifer host volatiles as attractants for the pine weevil, Hylobius abietis L. (Coleoptera: Curculionidae). J. Econ. Entomol. 1986, 79, 970-973. [CrossRef]

33. Nordlander, G. A method for trapping hylobius abietis (L.) with a standardized bait and its potential for forecasting seedling damage. Scand. J. For. Res. 1987, 2, 199-213. [CrossRef]

34. Erbilgin, N.; Szele, A.; Klepzig, K.D.; Raffa, K.F. Trap Type, Chirality of $\alpha$-Pinene, and Geographic Region Affect Sampling Efficiency of Root and Lower Stem Insects in Pine. J. Econ. Entomol. 2001, 94, 1113-1121. [CrossRef] [PubMed]

35. Nordlander, G. Limonene inhibist attraction to Alpha-pinene in the pine weevils Hylobius abietis and H. pinastri. J. Chem. Ecol. 1990, 16, 1307-1320. [CrossRef] [PubMed]

36. Olenici, N.; Duduman, M.L.; Teodosiu, M.; Olenici, V. Efficacy of artificial traps to prevent the damage of conifer seedlings by large pine weevil (Hylobius abietis L.) - A preliminary study. Bull. Transilv. Univ. Bras. 2016, 9, 9-20.

37. Stocki, J.S. The Use of Pheromones and Pheromone Traps in Forest Protection in Poland in the Years 1980-1997; Practice oriented results on the use and production of Neem ingredients and pheromones VIII; Kleeberg, H., Zebitz, C.P.W., Eds.; Druck \& Graphics: Giessen, Germany, 2000; pp. 128-133.

38. Skrzecz, I. Non-target insects in the pine weevil (Hylobius abietis L.) traps with Hylodor dispenser. Folia For. Polon. Ser. A For. 2003, 35, 27-35.

39. Voolma, K.; Siida, I.; Sibul, I. Forest insects attracted to ground traps baited with turpentineand ethanol on clear-cuttings. Nor. J. Entomol. 2001, 48, 103-110.

40. Wheater, C.P.; Bell, J.R.; Cook, P.A. Practical Field Ecology: A Project Guide; Wiley-Blackwell: Chichester, UK, 2011; p. 388.

41. Örlander, G.; Nilsson, U.; Nordlander, G. Pine weevil abundance on clear-cuttings of different ages: A 6-year study using pitfall traps. Scand. J. For. Res. 1997, 12, 225-240. [CrossRef]

42. Saalas, U. Suomen Metsähyönteiset; Finnish Forest Insects; Wsoy: Porvoo, Finland, 1949; p. 719.

43. Ozols, G. Prides un Egles Dedrofagien Kukaini Latvijas Mezos; (Dendrophagus insects of pine and spruce in Latvian forests); Zinātne: Riga, Latvia, 1985; p. 208.

44. Ehnström, B.; Axelsson, R. Insekts Gnag I Bark Och Ved; SLU: Uppsala, Sweden, 2002.

45. Längström, B. Abundance and seasonal activity of adult Hylobius-weevils in reforestation areas during the first years following final felling. Commun. Lnst. For. Fenn. 1982, 106, 1-23.

46. Maavara, V.; Merihein, A.; Parmas, H.; Parmasto, E. Metsakaitse; Valgus: Tallinn, Estonia, 1961; p. 733.

47. Luik, A.; Voolma, K. Some aspects of the occurrence, biology and cold-hardiness of Hylobius weevils. In Insects Affecting Reforestation: Biology and Damage; Alfaro, R.I., Glover, S.G., Eds.; Pacific and Yukon Region, Forestry Canada: Victoria, BC, Canada, 1989; pp. 28-33.

48. Viiri, H.; Miettinen, O. Feeding preferences of Hylobius pinastri Gyll. Balt. For. 2013, 19, 161-164.

49. Leather, S.R.; Ahmed, S.J.; Hogan, L. Adult feeding preferences of the pine weevil, Hylobius abietis (Coleoptera: Curculionidae). Eur. J. Entomol. 1994, 91, 385-389.

50. Varkonda, Š.; Florian, Š. Odparnik na regulované uvol'novanie prchavých látok; (Evaporator for controlled release of volatile substances) Utility model, SK 4570 U; Úrad Priemyselného Vlastníctva: Bratislava, Slovakia, 2006; p. 3.

51. Galko, J.; Kunca, A.; Ondruš, M.; Špilda, I.; Rell, S. Zhodnotenie a porovnanie nákladov na rôznu formu ošetrenia ihličnatých sadeníc proti tvrdoňovi smrekovému. In Aktuálne Problémy v Ochrane Lesa; Kunca, A., Nový Smokovec, S., Kunca, A., Eds.; Národné Lesnícke Centrum: Zvolen, Slovakia, 2015; pp. 101-105.

52. Thorin, J.; Nömmik, H. Monoterpene composition of cortical oleoresin from different clones of Pinus sylvestris. Phytochemistry 1974, 13, 1879-1881. [CrossRef]

53. Yazdani, R.; Nilsson, J.E. Cortical monoterpene variation in natural populations of Pinus sylvestris in Sweden. Scand. J. For. Res. 1986, 1, 85-93. [CrossRef]

54. Nordlander, G. Host finding in the pine weevil Hylobius abietis: Effects of conifer volatiles and added limonene. Entomol. Exp. Appl. 1991, 59, 229-237. [CrossRef] 
55. Squillace, A.E. Analyses of monoterpenes of conifers by gas-liquid chromatography. In Modem Methods in Forest Genetics; Miksche, J.P., Ed.; Springer: New York, NY, USA, 1976; pp. 139-157.

56. Voolma, K.; Sibul, I. The effect of collecting fluid on the catch results of Hylobius abietis in pitfall traps. Agron. Res. 2006, 4, 457-460.

57. Saintonge, F.X.; Malphettes, C.B. Un piege pour surveiller les populations d'hylobes (Hylobius abietis L.) (Coleop.: Curc.)? Etudes de Cemagref. Sér. For. 1991, 6, 138-155.

58. Charitonova, N.Z. Bolšoj Sosnovyj Dolgonosik I Borba s Nim; 1. Vyd; Lesnaja Promyšlennost Progress: Moskva, Russia, 1965; p. 88. ISBN 934-0-41-595-768-24.

59. Nordlander, G.; Örlander, G.; Langvall, O. Feeding by the pine weevil Hylobius abietis in relation to sun. exposure and distance to forest edges. Agric. For. Entomol. 2003, 5, 191-198. [CrossRef]

60. Bejer-Petersen, B.; Juutinen, P.; Kangas, E.; Bakke, A.; Butovitsch, V.; Eidmann, H.; Heqvist, K.J.; Lekander, B. Studies on Hylobius abietis L. I. Development and life cycles in the Nordic countries. Acta Entomol. Fenn. 1962, 17, 1-107.

61. Selander, J.; Kalo, P.; Kangas, E.; Pertunnen, V. Olfactory behavior of Hylobius abietis L. (Col., Curculionidae). I. Response to several terpenoid fractions isolated from Scots pine phloem. Ann. Entomol. Fenn. 1974, 39, $40-45$.

62. Nordenham, H.; Eidmann, H.H. Response of the pine weevil Hylobius abietis L. (Col., Curculionidae) to host volatiles in different phases of its adult life cycle. J. Appl. Entomol. 1991, 112, 353-358. [CrossRef]

63. Björklund, N.; Nordlander, G.; Bylund, H. Olfactory and visual stimuli used in orientation to conifer seedlings by the pine weevil, Hylobius abietis. Physiol. Entomol. 2005, 30, 225-231. [CrossRef]

64. Tilles, D.A.; Eidmann, H.H.; Solbreck, B. Mating stimulant of the pine weevil Hylobius abietis (L.). J. Chem. Ecol. 1988, 14, 1495-1503. [CrossRef] [PubMed]

65. Selander, J. Evidence of pheromone-mediated behaviour in the large pine weevil, Hylobius abietis (Coleoptera, Curculionidae). Ann. Ent. Fenn. 1978, 44, 105-112.

66. Mráček, Z.; Šrůtka, P. Stav znalostí a možnostech obrany proti klikorhu borovému (Hylobius abietis L.) v zemích Evropy. Zprávy Lesnického Výzk. 1984, 29, 21-25.

67. Solbreck, C.; Gyldberg, B. Temporal flight pattern of the large pine weevil, Hylobius abietis L. (Coleoptera, Curculionidae), with special reference to the influence of weather. Z. Angew. Entomol. 1979, 88, 532-536. [CrossRef]

(C) 2019 by the authors. Licensee MDPI, Basel, Switzerland. This article is an open access article distributed under the terms and conditions of the Creative Commons Attribution (CC BY) license (http://creativecommons.org/licenses/by/4.0/). 